\title{
Inventory Management Practices during COVID 19 Pandemic to Maintain Liquidity Increasing Customer Service level in an Industrial Products Company in Mexico
}

\author{
Ignacio Alvarez-Placencia*, Diana Sánchez-Partida, Patricia Cano-Olivos, José-Luis Martínez-Flores \\ Department of Logistics and Supply Chain Management, UPAEP University, 17 Sur 901, Barrio de Santiago, CP 72410 Puebla, \\ Puebla, México
}

\begin{tabular}{l} 
A R T I C L E I N F O \\
\hline Article history: \\
Received: 01 September, 2020 \\
Accepted: 26 October, 2020 \\
Online: 24 November, 2020
\end{tabular}

Keywords:

Customer Service

Inventory Control

Delivery Performance

Lean Manufacturing

\begin{abstract}
A B S T R A C T
This work presents the development and improvement obtained by implementing inventory managing practices during the COVID 19 pandemic in a Mexican company, a leader in the industrial sector to overcome the effects on the Company's economies due to constrained market to maintain liquidity and preserve employment by increasing customer service level ensuring the availability of the finished product and improving the delivery time in the distribution center, from the receipt of the customer's order, order picking, shipment preparation, invoicing and final delivery to the customer. The areas involved are Commercial, Demand and Materials Planning, Purchasing, Manufacturing, Logistics, and Operations of the Distribution Center. The deployment process considered an ABC study, analysis of the historical demand, product inventory coverage days, analysis of the lead time components of the distribution center, to implement a minimum and maximum inventory control policy for the product portfolio $A$ and manufacture products classified as $B$ and $C$ on a make to order basis, an audit was performed of its distribution center, to identify opportunities for improvement in their processes to reduce the time of delivery to the customer.

The Company was not in compliance with the level of customer service with an 89\% performance due to the low availability of the finished product inventory, affecting the customer's delivery time in the distribution center with a time of 5 hours versus the goal of 90 minutes per event.

The implementation of the improvement achieved an increase in the level of service up to 5\% starting the fourth quarter of 2019, the savings in inventory optimization at an annual base represented USD 530,785.00 (Five hundred thirty thousand seven hundred eighty-five dollars), and the Company has implemented this good practice nationwide in its other Manufacturing Plants and Distribution Centers as part of the strategic corporate policy deployment.
\end{abstract}

\section{Introduction}

The value chain is all actions to make a product to flow from the raw material to the customer's hands. Within the value chain, the primary processes include the transformation of the product, inbound logistics that is the delivery of suppliers of the raw material to a warehouse of the manufacturing Company, the logistics of operations whose purpose is the proper administration of the raw material in the transformation process to ensure the availability of raw material inventory or inventory in process in the work centers and finally the outbound logistics from the storage, distribution and perfect delivery of the finished product to the end customer [1].

\footnotetext{
*Corresponding Author: Ignacio Alvarez-Placencia, ignacio.alvarez@upaep.edu.mx www.astesj.com
}

https://dx.doi.org/10.25046/aj050675
The secondary processes in a value chain are the ones that give support to the primary processes for the transformation of the product. The timeline determines the response time of the value chain, and the flow of information in the value chain is essential because it includes the release of the sales estimate, placement of the customer order, release of the purchase orders and manufacturing orders to the delivery of the product to the end customer [1].

The efficiency and optimization of the distribution center's functions is a priority for the achievement of the goal of perfect delivery to the customer and inventory availability assurance to ensure the desired service level [2]. 
This case study's scope is a company of $100 \%$ Mexican capital, market leader, is dedicated to the production and marketing of industrial products located in Mexico with ten manufacturing plants and three Distribution Centers with 800 employees.

This case study helps the Company to face COVID 19 pandemic with a constrained market to contain the economic effects of the pandemic that we are facing helping to preserve employment as much as possible and provide liquidity to create the conditions for the recovery of economic growth by ensuring the availability of the inventory of its products to meet the level of delivery service on time and improve the delivery time to the customer in the distribution center through an audit in the distribution center, establish a baseline of product inventory coverage days, analysis of the lead time components of the distribution center, value chain mapping, ABC classification of finished products, inventory control implementation with the maximum and minimum methodology, production balancing, measurement of customer's delivery time as days of inventory coverage in the distribution center.

Masaaki Imai, in his work, "Kaizen, The Key to Japanese Competitiveness," mentions that Japanese companies follow a defined strategic planning scheme; the administration develops and communicates the rules of the game: transparent processes, that is, with a standard procedure for Operation. It translates into top management shall first establish policies and procedures for all critical operations, then communicate and ensure that they are understood by all levels [3].

The rest of the research work consists of describing the case study, theoretical framework, and research methodology as its conclusions and results obtained.

\section{Literature Review}

According to the customer's perspective, the value chain's purpose is to determine which activities are value-added and nonvalue-added [4]. All activity that transforms the product should be understood as an added value; in contrast, all the activities that do not transform the product are no value-added. They are known as waste: Reworks, defects, unnecessary movements, inventories, waiting times, overproduction, unnecessary space, and transportation. This waste shall be eliminated to improve the value chain [5].

A distribution center is a vital component of the value chain for any company to achieve perfect delivery to the product customer as to the quantity, time, price, quality, and correct information.

The distribution center functions include receipt, inspection, storage, picking, preparation of shipment, dispatch, consolidation of orders, and final delivery to the customer. The efficiency of these activities is critical to ensure speed and optimize the flow of the product to reduce the response time and operating costs, from receipt of the customer's order to delivery, to send the products with the correct specification, quality, price with proper documentation to the customer. Always searching for continuous improvement to reduce waste as mentioned earlier and add only value in the supply chain.
The correct management of the distribution center supports the strategic objectives of the Company: Generate more sales, profit margin, cash flow, stability in the jobs satisfying customer demand with the correct level of service.

Therefore, storage and distribution activities for the product should be regarded as a vital component of the Company's strategic planning for it to be coupled with the expectations raised in the business plan [6].

The management of the Company must consider several factors to maintain optimal inventory levels, such as the financial liquidity of the Company, sales behavior such as seasonality, reliability, and availability of suppliers, available financial resources. An adequate level of inventory reduces the potential risks of lost sales due to the lack of inventory availability as well as an increase in the cash flow of the Company, such as the release of warehouse capacity [7].

It is strategic for the companies to achieve a high level of customer service with a minimum level of inventory by implementing the Lean Pull Replenishment methodology by having product's supermarkets for the products that represent $80 \%$ of the Company's revenues which inventory is replenished based on the consumer's signal at the time of consumption and made to order for those products that represent the other $20 \%$ of the Company's revenue. The Lean Pull Replenishment methodology should be coupled with the Process Capability analysis to reduce variation in processes and determine the processing capabilities of the Company through the commitment of the delivery date of the customer's order [8].

Inventory in the lean philosophy is viewed as a waste given that it impacts the cash flow of the Company when it is not in the correct amount; besides, the Company requires an expense to manage it, at the same time, it hides problems such as downtime of machinery, long periods of changeover of products, quality problems, lack of reliability of suppliers' performance among others. Therefore, it is essential to focus on reducing the longest process lead time and reduce inventory. It is vital to take into consideration synchronization between processes with a correct balanced production plan as well as reduce the change over time between products for each of the processes and always work with small batch sizes and avoid overproduction [9].

In the implementation of a continuous flow, the reduction of equipment change over times is vital, which consequently translates into smaller lot sizes aligned with a KanBan signaling system with an adequate plant layout allowing to achieve improvements in the reduction of manufacturing delivery times, thereby reducing work in process and finished goods inventories, eliminating unnecessary movements of materials resulting in having the correct level of inventory to meet customer demand and thus increase the customer service level [10].

It is essential to align the demand planning by reducing the variation of the demand estimate and leveling the demand, establishing EOQ to determine the optimum lot size to produce to minimize the ordering and logistic costs of maintaining the inventory, also optimizing equipment change over times allows reducing the number of Kanban cards which results in a reduction of storage space such as the transport of materials by creating a 
continuous flow in the value chain and making timely deliveries to the customer [11].

Within the investigation of inventory management, the optimization strategy stands out; the correct coordination of prices and inventory management technology is vital. Many companies begin to improve logistics by applying inventory control technology to reduce costs. The opportunity lies in ensuring having enough inventory to meet demand by minimizing inventory costs in the right place and time [12].

Any improvement in inventory performance has an impact on the quality of the product as well as the financial performance of the Company, so management must pay attention to proper inventory management. Companies without sufficient financial liquidity to obtain better financial performance can improve product quality by improving inventory management [13].

The correct inventory management practices have a direct impact on working capital, production, and the level of customer service and sales. Goods inventory management practices include having the correct levels of raw material and in-process inventory to ensure the continuous flow of supply to production, to avoid stoppages of the production line, to anticipate the correct prices of materials, ensure the correct levels of inventory of finished product to complete customer orders, follow the customer's demand to increase the level of service provided to the same [14].

The ABC Inventory Classification usually considers the annual volume multiplied times the ordered price in a descending manner classified into three categories A, B, and C. According to the $\mathrm{ABC}$ classification, the same service level is assigned for each part number according to the classification. Regularly, the articles generate the most considerable profit and are considered higher levels of service. To classify each of the part numbers, a new approach that takes into account four parameters is proposed: the cost of having a shortage times the rate of demand, divided into the cost of maintaining the inventory (purchase price) times the amount to be ordered for each of the articles; the result is sorted in descending order and is classified on $\mathrm{ABC}$, which considers three classes: $50 \%, 30 \%$ and $20 \%$, where A must have the highest level of service, followed by B and C [15].

Once certain products classified as type A, for the calculation of finished product inventory level, known as supermarket Figure 1 , the following formula is considered [16]:

\begin{tabular}{|c|l|l|}
\hline \multicolumn{2}{|c|}{$\begin{array}{c}\text { Average daily demand } \mathrm{x} \\
\text { Replacement delivery period }\end{array}$} & $\begin{array}{l}\text { Stock for the } \\
\text { cycle }\end{array}$ \\
\hline+ & $\begin{array}{l}\text { Demand Variation \% } \\
\text { (stock for the cycle) }\end{array}$ & Buffer stock \\
\hline+ & $\begin{array}{l}\text { Security Factor \% } \\
\text { (stock for the cycle }+ \\
\text { buffer stock) }\end{array}$ & Security stock \\
\hline$=$ & & $\begin{array}{l}\text { Supermarket } \\
\text { stock }\end{array}$ \\
\hline
\end{tabular}

Figure 1: Approach to the calculation of the supermarket inventory level

The supermarket inventory is equal to the stock for the cycle (it is the average demand of each product classified type A, which considers the replenishment delivery time. Replenish time is the period elapsed from the date the order is received, manufactured, and made available at the warehouse) plus buffer stock (which is the amount of each product to be placed to cover any supply variation, such as quality defects, equipment stoppages, personnel missing, raw materials shortage). This supermarket shall be revised daily to ensure finished product availability to comply with service level upon any variation in demand or supply.

Inventory management with a maximum and minimum policy established on this case study for the industrial products industry has also been applied as the policy to health services, which have considered the importance of ensuring the supply of medicine, as well as a level of safety stock inventory to have continuity in the service in the event of supply shortages. By having a correct level of service and reducing delivery times, the decrease in inventory level is favored. The factors contributing to a shortage in medication shall be known, and evaluation is to be made from the demand pattern and all processes of the value chain intervening up to the delivery of the medication [17].

\section{Problem Statement}

The Company is committed to a quality management system that seeks to continuously improve profitability, customer satisfaction, internal processes, and staff development through the fulfillment of quality objectives and has considered strengthening its continuous improvement process in the distribution center located on the main plant solving the next opportunity for improvement: Position the correct level of finished product inventory under A classification, to increase the level of service to $95 \%$ as the preparation of shipment is interrupted due to the shortage of finished products for direct sale to or transferred to other manufacturing plants of the Company, having to reschedule shipments impacting the Company's sales, improve response time in the distribution center from the receipt of the finished product, collection of the product according to the customer's order, preparation of shipment, invoicing and clearance to 90 minutes.

Change management for continuous improvement as outlined in his Theory of Constraints (TOC) concepts and principles for improving companies' performance by focusing on some restrictions in the system. These influence points are system restrictions [18] [19].

\section{Methodology}

It is necessary to validate if the processes are oriented to serving the customer and achieve a high standard of service level to understand the value chain's baseline of performance. For this purpose, a mapping of the value chain is performed, which is a tool of lean manufacturing that is carried out by product family which outlines the value chain, customers, primary and secondary processes, suppliers, flows of information, and timeline, to display the waste, non-value-added activities and take actions to eliminate them. First, the map of the value chain in current status is carried out to identify the waste, which is transportation, inventory, movements, waiting, over-processing, overproduction, and defects; improvement events known as Kaizen are proposed to eliminate waste and streamline the value chain and therefore map the ideal state [2].

$\mathrm{ABC}$ analysis for inventory management is a method of inventory classification to book value (cost or acquisition) of the materials stored that considers the use of the article by its book value, classified from highest to lowest [20]. 
The principle of ABC analysis in inventory management applies:

1) In the classification of inventory items, based on their relative importance.

2) By setting different administrative controls for different classifications of materials and setting different degrees of control according to each classification's different ranges.

The criterion of classification should reflect the difficulty of controlling an article and the impact of this on the cost and in profit.

The ABC analysis determines the importance of an article in the Company's inventory. To perform this classification, companies could consider some of these no limitation criteria:

1) The annual transaction volume of an article (valued monetarily).

2) Shortages of material used in the production of an article.

3) Delivery time.

4) Storage requirements of an article.

5) Risk of theft.

6) Useful life.

7) Cost of a shortage of inventory, among other criteria.

The criterion used in this case study for the ABC classification is the volume of sales valued monetarily considering the last six months of current sales.

For classified items A, inventory control of maximum and minimum inventory method is implemented, which is a system specially developed to achieve up-to-date warehouses control and achieve optimal inventory; it sets the maximum and minimum levels of stock for each product, as shown below:

Definition of Variables:

$\bar{x}=$ Average sales in three months.

$T_{\text {Info }}=$ Time since the manufacturing plant receives the request from the distribution center.

$T_{m f g}=$ time to manufacture considers the days the manufacturing plant requires to produce the finished product.

$T_{\text {transit }}=$ time in transit from the plant warehouse to the distribution center.

Var. $T_{\text {transit: }}$ Time the shipment may be delayed from the main plant warehouse to the distribution center.

Frec.Emb: Shipment frequency. Several days between each shipment.

Var.Dem. = Demand variation in days needed as additional coverage in the event of any demand fluctuation.

Equations for the calculation of maximum and minimum inventory:

The minimum inventory is calculated based on the average daily demand times the replenish lead time [16].

$$
\text { Min.Inventory }=\bar{X}^{*}\left(T_{\text {Info }}+T_{m f g}+T_{\text {transit }}+\text { Var.Ttransit }+\right.
$$$$
\text { Frec.Emb) }
$$

The maximum inventory is calculated based on the average daily demand times the replenish lead time in days plus the variation of the demand in days to have additional coverage for any demand fluctuation [16].

$$
\begin{gathered}
\text { Max.Inventory }=\bar{x} *\left(\begin{array}{c}
T_{\text {Info }}+T_{m f g}+T_{\text {transit }}+\text { Var. Ttransit } \\
+ \text { Var.Dem }
\end{array}\right) \\
\text { Optimal inventory }=\frac{\text { (Min Inventory }+ \text { Max Inventory })}{2}
\end{gathered}
$$

The reorder point is the point when the inventory drops to a certain level, an order for a predetermined amount to replenish the inventory within the supplier's time of delivery is placed. This type of system can be used effectively for articles with independent demand. The reorder point is established to cover the average use within the delivery time plus variation in demand or variation in delivery time. The inventory to absorb this variation is known as safety stock. The amount of variation to cover depends on the level of customer service desired [20].

The safety stock (SS) required is a function of the random variation in demand during the estimated period, the desired level of customer service, and the radius of the delivery time during the estimated period.

$$
S S=z S \sqrt{L T}
$$

Where SS is the safety stock in a warehouse, $\mathrm{z}$ is the level of service sought for the Company represented by the value of the area under the curve, $\mathrm{s}$ is the standard deviation of the product demanded in the warehouse per unit of time.

Once inventory levels are set, next is the leveling of manufacturing within a period. It allows avoiding fluctuations to make the consumption of raw material, labor, and production capacity more predictable, ensuring finished product availability, minimizing inventory, working capital, and lead time throughout the value chain [16].

For this proposal, it is transcendent to determine the control condition of the process before the proposed improvements, as well as the determination of process capability indexes before the improvements and the associated sigma level thereof, to have transcendent measurements

To establish the central distribution center's baseline of performance, the Auditing Warehouse Performance, Ohio: Ackerman Publications checklist was applied [21].

Table 1: Summary of results of the Audit Central Distribution Center

\begin{tabular}{|l|c|c|c|c|}
\hline AREA & WEIGHT & RANK & $\begin{array}{l}\text { MAX } \\
\text { RANK }\end{array}$ & GAP \\
\hline External & 0.05 & 0.117 & & \\
\hline Internal & 0.05 & 0.126 & & \\
\hline $\begin{array}{l}\text { Warehouse } \\
\text { IT systems }\end{array}$ & 0.1 & 0.3 & 0.4 & 0.1 \\
\hline
\end{tabular}




\begin{tabular}{|l|c|c|c|c|}
\hline $\begin{array}{l}\text { Mechanical } \\
\text { handling } \\
\text { equipment }\end{array}$ & 0.1 & 0.264 & 0.4 & 0.136 \\
\hline $\begin{array}{l}\text { Contingency } \\
\text { planning }\end{array}$ & 0.05 & 0.067 & & \\
\hline $\begin{array}{l}\text { Inbound } \\
\text { operation }\end{array}$ & 0.1 & 0.211 & 0.49 & 0.278 \\
\hline $\begin{array}{l}\text { Put-away and } \\
\text { storage }\end{array}$ & 0.05 & 0.14 & & \\
\hline Stock control & 0.15 & 0.417 & 0.6 & 0.183 \\
\hline Picking & 0.05 & 0.15 & & \\
\hline Dispatch & 0.15 & 0.48 & 0.72 & 0.24 \\
\hline $\begin{array}{l}\text { Staff and } \\
\text { housekeeping }\end{array}$ & 0.05 & 0.123 & & \\
\hline $\begin{array}{l}\text { Warehouse - } \\
\text { performance } \\
\text { management }\end{array}$ & 0.05 & 0.1 & & \\
\hline $\begin{array}{l}\text { Legislative \& } \\
\text { Health and } \\
\text { Safety } \\
\text { requirements }\end{array}$ & 0.05 & 0.154 & & \\
\hline $\begin{array}{l}\text { Overall } \\
\text { Warehouse } \\
\text { Rating }\end{array}$ & & 2.648 & 3.585 & \\
\hline
\end{tabular}

\begin{tabular}{|c|c|c|c|c|}
\hline 1 & 2 & 3 & 4 & 0 \\
\hline No & Poor & Good & Excellent & N/A \\
\hline
\end{tabular}

Overall, the general grade of DC was 2.648, which indicates performance with an opportunity for improvement. When considering the ascribed areas as the most important in the auditing process, the maximum range was calculated. It denotes three areas with an opportunity for significant improvement:

1) Inbound Operation with a gap of 0.278 .

2) Dispatch with a gap of 0.240 .

3) Stock Control with a gap of 0.183 .

If efforts are focused on these three areas, then a potential score of 3.459 can be reached to be close to excellence with a rating of 4 .

Hence, the efforts will be focused on the following processes:

a) Receipt, Preparation of the Shipping Order \& Inventory Control. It interrupts the shipment's preparation flow due to finished goods and raw material shortage in the main warehouse, which causes reschedule shipments to the distribution centers based on the promised delivery date of production and suppliers. Evaluate the option to implement a pre-shipment activity and implement a performance metric of hours of preparation and loading of the shipment.

b) Dispatching requires a shipment schedule to increase flexibility associated with sales to customers based on available resources as workforce, space, and equipment.

c) One of the audit opportunities is the lack of KPI's to monitor CD's performance. Customer's delivery time, one of the top priorities identified by the commercial area, currently is 5 hours, being the goal of an average time of 90 minutes. d) In the stock control process, the opportunity is detected to implement an inventory control to guarantee the inventory's availability due to the constant interruption in the picking process due to finished goods inventory shortage compromising the shipment program and impacting the customer service level.

Associated with the delivery of the finished product to the customer, transformation processes were evaluated to understand the flow of the value chain of the Company, from suppliers, production processes, distribution and final delivery of customer, as well as the activities that provide service to primary processes, which involves the creation of the customer order, the administration area authorizes the order, the ordered product inventory is booked, delivery of documents to logistics, processing the loading order, delivery of documents to the loading area, loading of order and delivery of documents to the customer. Value stream mapping is a tool to achieve competitiveness in any company's value chain, highlighting the inefficiencies of processes such as areas for improvement [22].

The value stream map of the current state indicates:

- The model is pushed and does not have a sales estimate from the commercial area.

- Orders flow into the commercial area, and there is no supermarket of the finished product to shorten the delivery time to the customer and act as a buffer to absorb changes in demand.

- The production plan is made based on the demonstrated demand, and a production signal is sent to production based on a weekly production plan that applies to each of the work centers, which takes into account proven capacity and labor requirements.

- Material planning is done based on an MRP that explodes customer requirements to validate inventory position and release the production orders.

- The suppliers do not estimate the future requirement of the raw materials, so they react based on the monthly supply signal sent by the purchasing department.

$\mathrm{ABC}$ analysis was performed, Table 2, which considered the sale of each Distribution Center (DC) for each of the finished products by book value, based on manufacturing and sorted from highest to lowest. The Company's approach resides in 52 catalogs to implement the inventory control policy of maximums and minimums in Central Distribution Center, 18 catalogs in Distribution Center in City one, and 21 catalogs in City two Distribution Center, as it is shown below:

DC Central

\begin{tabular}{|l|c|c|}
\hline ABC & $\begin{array}{l}\text { Total } \\
\text { Catalogs }\end{array}$ & $\begin{array}{l}\text { \%Sales } \\
\text { Value }\end{array}$ \\
\hline A & 52 & 80 \\
\hline B & 68 & 15 \\
\hline C & 207 & 5 \\
\hline
\end{tabular}

DC City 1

\begin{tabular}{|l|l|l|}
\hline ABC & $\begin{array}{l}\text { Total } \\
\text { Catalogs }\end{array}$ & $\begin{array}{l}\text { \%Sales } \\
\text { Value }\end{array}$ \\
\hline
\end{tabular}




\begin{tabular}{|l|c|c|}
\hline $\mathrm{A}$ & 18 & 80 \\
\hline $\mathrm{B}$ & 31 & 15 \\
\hline $\mathrm{C}$ & 58 & 5 \\
\hline
\end{tabular}

DC City 2

\begin{tabular}{|l|c|c|}
\hline ABC & $\begin{array}{l}\text { Total } \\
\text { Catalogs }\end{array}$ & $\begin{array}{l}\text { \%Sales } \\
\text { Value }\end{array}$ \\
\hline A & 21 & 80 \\
\hline B & 26 & 15 \\
\hline C & 68 & 5 \\
\hline
\end{tabular}

When reviewing the inventory's coverage in the days of the finished goods classified as type A, there is an average inventory coverage of 27 days, compared against the Company's goal of 14 inventory days. The following Table 3 shows a summary of coverage in the inventory days before the implementation of the improvement:

Table 3: Coverage in days and distribution as a percentage of the value of inventory catalogs classified as Type A

\section{Central}

\begin{tabular}{|l|r|r|}
\hline \multicolumn{1}{|c|}{ DOS } & $\begin{array}{c}\text { Number of } \\
\text { Finished } \\
\text { Goods }\end{array}$ & $\begin{array}{c}\text { \% of } \\
\text { Inventory } \\
\text { Value }\end{array}$ \\
\hline 0 Days & 7 & $3 \%$ \\
\hline From 1 to 14 days & 12 & $7 \%$ \\
\hline From 15 to 22 days & 13 & $53 \%$ \\
\hline From 23 to 30 days & 6 & $17 \%$ \\
\hline $\begin{array}{l}\text { Greater than 30 } \\
\text { days }\end{array}$ & 12 & $20 \%$ \\
\hline Total & 50 & $100 \%$ \\
\hline
\end{tabular}

DC City 1

\begin{tabular}{|l|r|r|}
\hline \multicolumn{1}{|c|}{ DOS } & $\begin{array}{c}\text { Number of } \\
\text { Finished } \\
\text { Goods }\end{array}$ & \multicolumn{1}{c|}{$\begin{array}{c}\% \text { of } \\
\text { Inventory } \\
\text { Value }\end{array}$} \\
\hline 0 Days & 1 & $0 \%$ \\
\hline From 1 to 14 days & 8 & $57 \%$ \\
\hline From 15 to 22 days & 2 & $18 \%$ \\
\hline From 23 to 30 days & 3 & $9 \%$ \\
\hline $\begin{array}{l}\text { Greater than } 30 \\
\text { days }\end{array}$ & 4 & $16 \%$ \\
\hline Total & 18 & $100 \%$ \\
\hline
\end{tabular}

DC City 2

\begin{tabular}{|l|r|r|}
\hline \multicolumn{1}{|c|}{ DOS } & $\begin{array}{c}\text { Number of } \\
\text { Finished } \\
\text { Goods }\end{array}$ & $\begin{array}{c}\text { \% of } \\
\text { Inventory } \\
\text { Value }\end{array}$ \\
\hline 0 Days & 2 & $0 \%$ \\
\hline From 1 to 14 days & 10 & $43 \%$ \\
\hline From 15 to 22 days & 4 & $19 \%$ \\
\hline From 23 to 30 days & 3 & $33 \%$ \\
\hline $\begin{array}{l}\text { Greater than 30 } \\
\text { days }\end{array}$ & 2 & $5 \%$ \\
\hline Total & 21 & $100 \%$ \\
\hline
\end{tabular}

Next, the state of statistical process control regarding the original process is shown and the capability index, $\mathrm{Z}$ level, and associated sigma [23].

A prerequisite to determine the status of control of a process is to validate that the data analyzed corresponds to a standard distribution. Figure 2, which can be validated and with the value $\mathrm{p}=0.191$, is higher than the level of type I error or $\alpha=0.05$.

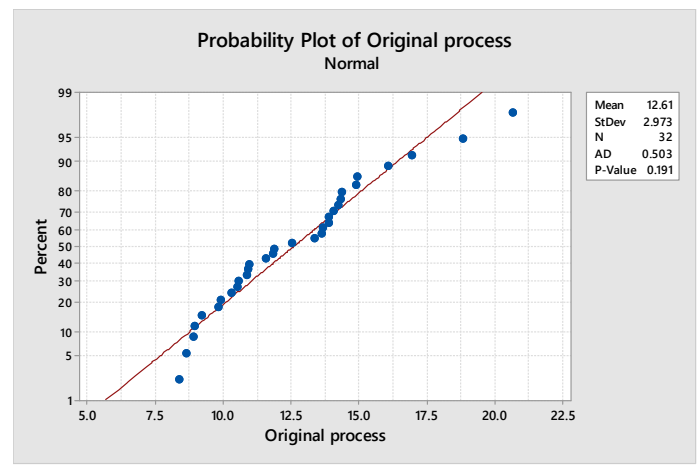

Figure 2: Normal Probability Graph

In Figure 3, it can be noticed that the process is out of statistical control due to several measuring points, which are outside control limits, which are associated with sources of variation attributable to the conditions of the current process [23].

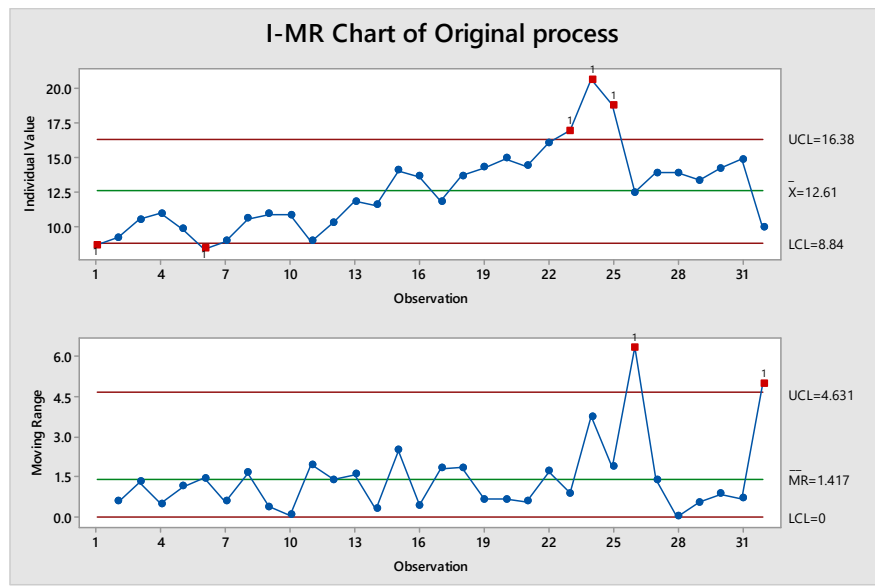

Figure 3: Control Chart for Individual Values and Mobile Range of the original process

Figure 4 shows the capability process analysis report for the original process. The cpk index establishes the actual process capability to meet specifications to consider that a process is adequate; the value must be higher than 1.25 [23]. the current cpk value of the process is 0.37 , so the process under current conditions cannot meet specifications and requires serious intervention to restructure its activities and operation controls. The $\mathrm{Z}$ level of the process is 1.11 , which is reflected in the sigma level $=2.61$, the sigma level of a process is determined by the value of the $Z+1.5$ level associated with the general standard deviation of the process. It should be noted that the lower specification limit is considered suitable; hence efforts will be concentrated on the upper specification limit [23]. 


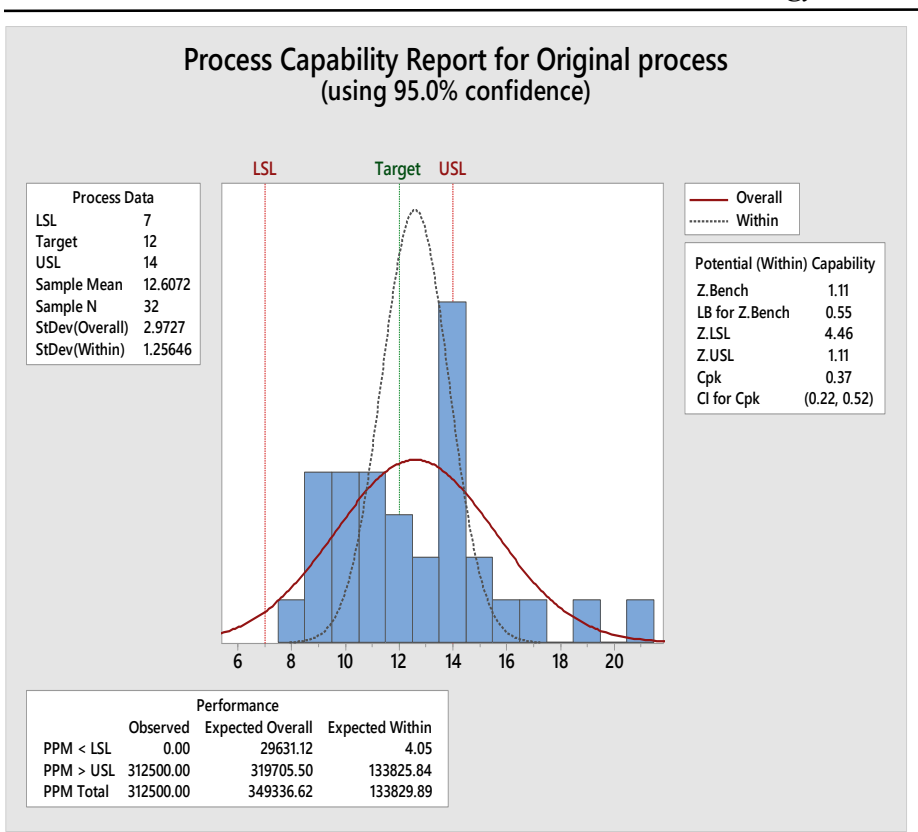

Figure 4: Process Capability report for the original process

The graph of the performance of the process shown in Figure 5 allows observing the fraction of the process that fails to comply with the established specifications. It can be seen in the area under the curve that exceeds the upper control limit.

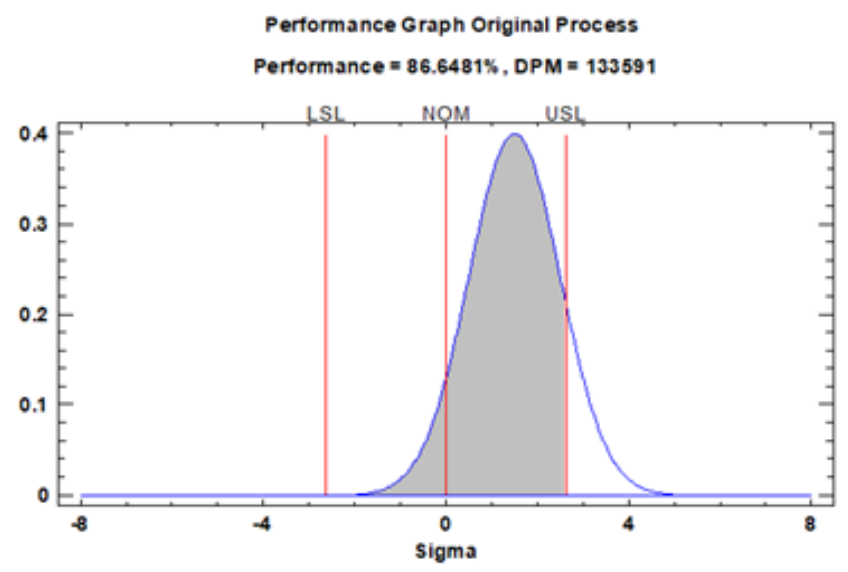

Figure 5: Performance Graph for the original process.

In the six sigma calculator associated with the process Table 4, the values obtained are the $Z$ value of 1.11, Defects Per Million (DPM) of 133,519, Percentage of Defects 13.3, Yield of $86.64 \%$ with a process capability (Cpk) of 0.37 , and a sigma quality level (SQL) of 2.6 [23].

\begin{tabular}{|c|c|}
\hline Table of Contents & Volue \\
\hline Value-Z & 1.11 \\
\hline DPM & 133519 \\
\hline Defects & 13.3519 \\
\hline Performance & 86.6481 \\
\hline Cpk & 0.37 \\
\hline SQL & 2.61 \\
\hline
\end{tabular}

\section{Issues, Controversies and Problems}

Based on the audit, other opportunities were identified and then raised to the Company:

1) Improve the receiving flow of raw materials and finished product, since the schedule for the reception of raw material as complementary products for sale is interspersed with the hours of shipment preparation, which generates a conflict of space in the yard and rescheduling of shipments of the finished product.

2) Review the flow of finished products from other manufacturing plants to ensure the availability of inventory in the central distribution center, positioning a supermarket to facilitate the consolidation of shipments.

3) Streamline the work used in the Operation of the process put away (pre-stowage to the final location of the finished product) combined with the efforts of picking Operation for the shipment of the product and create a standardized work for the truck loading process.

\section{Research Methodology}

In the implementation of the improvement of the customer service level to guarantee the availability of the finished product and improve the delivery time in the distribution center, the following results were obtained:

1) Audit in the central distribution center to detect improvement opportunities, where the detail of such is presented in the analysis of Table 1.

2) The $\mathbf{A B C}$ classification was performed to determine the items that represent $80 \%$ of the sales valued, to focus on the control of inventory presented in Table 2 .

3) The analysis of the coverage of inventory of finished product catalogs, Table 3 , classified as type $\mathrm{A}$, indicates that seven catalogs of finished product do not have inventory for sale, only twelve catalogs are within the target set by the Company of fourteen days of inventory, and the rest of the twenty-nine catalogs are above the goal of fourteen days of inventory. Only $7 \%$ of the total monetary value of the stock is located within the established goal of inventory coverage.

4) Lead Time Component Analysis

a) Information Lead Time: Time from the moment the manufacturing facility receives the request for inventory replenishment from the distribution center supermarket.

b) Manufacturing Lead Time: Considers the days that require the manufacturing facility to produce the finished product, plus the quarantine time.

c) In Transit Lead Time: Time in transit from the warehouse of the manufacturing facility to the distribution centers.

d) In Transit Lead Time Variation: Time that can delay the shipment from the warehouse manufacturing facility to the distribution center due to external factors such as climate, holidays, transport breakdown, among others.

e) Frequency of Shipments: Considers the period in days between each shipment.

f) Variation of Demand: Days of daily inventory coverage regarding the daily sales average to cover any variation in demand required by the final customer. 
g) Variation of Supply: Daily coverage based on average daily production to cover any variation in the supply as quality defects, equipment stoppage, lack of personnel, shortage of raw material.

The evaluation of lead time's components for the manufacturing facility is considered in the following Table 5:

Table 5: Manufacturing Lead Time Components

\begin{tabular}{|l|c|}
\hline $\begin{array}{l}\text { Manufacturing Lead Time } \\
\text { Components }\end{array}$ & Days \\
\hline Information Lead Time & 2 \\
\hline Manufacturing Lead Time & 1 \\
\hline Quarantine Lead Time & 7 \\
\hline Supply Variation & 10 \\
\hline
\end{tabular}

For the case of a distribution center, the lead time components are shown in the following Table 6:

Table 6: Lead Time Components for the Distribution Centers

\begin{tabular}{|l|c|}
\hline DC Central Lead Time Components & Days \\
\hline Information Lead Time & 2 \\
\hline Manufacturing Lead Time & 7 \\
\hline In Transit Lead Time & 0 \\
\hline In Transit Variation & 0 \\
\hline Shipment Frequency & 1 \\
\hline Demand Variation & 7 \\
\hline
\end{tabular}

\begin{tabular}{|l|c|}
\hline DC City 1 Lead Time Components & Days \\
\hline Information Lead Time & 2 \\
\hline Manufacturing Lead Time & 7 \\
\hline In Transit Lead Time & 1 \\
\hline In Transit Variation & 0 \\
\hline Shipment Frequency & 3 \\
\hline Demand Variation & 3 \\
\hline
\end{tabular}

\begin{tabular}{|l|c|}
\hline DC City 2 Lead Time Components & Days \\
\hline Information Lead Time & 2 \\
\hline Manufacturing Lead Time & 7 \\
\hline In Transit Lead Time & 1 \\
\hline In Transit Variation & 0 \\
\hline Shipment Frequency & 3 \\
\hline Demand Variation & 2 \\
\hline
\end{tabular}

\begin{tabular}{|l|c|}
\hline DC Central Lead Time Components & Days \\
\hline Information Lead Time & 2 \\
\hline Manufacturing Lead Time & 7 \\
\hline In Transit Lead Time & 0 \\
\hline In Transit Variation & 0 \\
\hline Shipment Frequency & 1 \\
\hline Demand Variation & 7 \\
\hline
\end{tabular}

\section{5) Inventories Planning for the distribution centers and} manufacturing facility

The sales estimate horizon is three months (current month plus two months based on the historical demand), the demand is analyzed based on the current sales and sales estimate provided by the commercial area Table 7 for calculations of supermarkets to position each of them in the distribution centers.

Table 7: Demand for each Distribution Center

Central Distribution Center

\begin{tabular}{|l|r|r|r|l|r|l|}
\hline Catalog & $\begin{array}{l}\text { Aug } \\
19\end{array}$ & $\begin{array}{l}\text { Sep } \\
19\end{array}$ & $\begin{array}{l}\text { Oct } \\
19\end{array}$ & $\begin{array}{l}\text { Nov } \\
19\end{array}$ & $\begin{array}{l}\text { Dec } \\
19\end{array}$ & \\
\hline $\mathbf{8 7 5 0}$ & \multicolumn{1}{|c|}{286} & 92 & 138 & 272 & 227 & \\
\hline $\mathbf{6 8 9 0}$ & 271 & 219 & 210 & 169 & 150 & \\
\hline $\mathbf{5 1 5 1}$ & 78 & 170 & 61 & 162 & 94 & \\
\hline
\end{tabular}

Central Distribution Center

\begin{tabular}{|l|l|l|l|l|l|l|}
\hline Catalog & $\begin{array}{l}\text { Jan } \\
20\end{array}$ & $\begin{array}{l}\text { Feb } \\
20\end{array}$ & $\begin{array}{l}\text { Mar } \\
20\end{array}$ & $\begin{array}{l}\text { Apr } \\
20\end{array}$ & $\begin{array}{l}\text { May } \\
20\end{array}$ & Jun 20 \\
\hline $\mathbf{8 7 5 0}$ & 307 & 307 & 314 & 215 & 205 & 205 \\
\hline $\mathbf{6 8 9 0}$ & 260 & 313 & 282 & 215 & 200 & 200 \\
\hline $\mathbf{5 1 5 1}$ & 18 & 62 & 59 & 60 & 50 & 50 \\
\hline
\end{tabular}

City 1 Distribution Center

\begin{tabular}{|l|r|r|r|r|l|r|}
\hline Catalog & $\begin{array}{l}\text { Aug } \\
19\end{array}$ & $\begin{array}{l}\text { Sep } \\
19\end{array}$ & $\begin{array}{l}\text { Oct } \\
19\end{array}$ & $\begin{array}{l}\text { Nov } \\
19\end{array}$ & $\begin{array}{l}\text { Dec } \\
19\end{array}$ & \\
\hline $\mathbf{8 7 5 0}$ & 2 & 8 & 23 & 6 & 7 & \\
\hline $\mathbf{6 8 9 0}$ & 19 & 139 & 119 & 197 & 140 & \\
\hline $\mathbf{5 1 5 1}$ & 58 & 28 & 155 & 140 & 100 & \\
\hline
\end{tabular}

City 1 Distribution Center

\begin{tabular}{|l|r|r|r|r|r|r|}
\hline Catalog & $\begin{array}{l}\text { Jan } \\
20\end{array}$ & $\begin{array}{l}\text { Feb } \\
20\end{array}$ & $\begin{array}{l}\text { Mar } \\
20\end{array}$ & $\begin{array}{l}\text { Apr } \\
20\end{array}$ & $\begin{array}{l}\text { May } \\
20\end{array}$ & Jun 20 \\
\hline $\mathbf{8 7 5 0}$ & 2 & 1 & 0 & 13 & 13 & 9 \\
\hline $\mathbf{6 8 9 0}$ & 230 & 211 & 293 & 171 & 140 & 128 \\
\hline $\mathbf{5 1 5 1}$ & 177 & 88 & 126 & 92 & 43 & 43 \\
\hline
\end{tabular}

City 2 Distribution Center

\begin{tabular}{|c|r|r|r|r|r|c|}
\hline Catalog & $\begin{array}{c}\text { Aug } \\
19\end{array}$ & $\begin{array}{c}\text { Sep } \\
19\end{array}$ & $\begin{array}{c}\text { Oct } \\
19\end{array}$ & $\begin{array}{c}\text { Nov } \\
19\end{array}$ & $\begin{array}{c}\text { Dec } \\
19\end{array}$ & Catalog \\
\hline $\mathbf{8 7 5 0}$ & 53 & 25 & 6 & 39 & 52 & 8750 \\
\hline $\mathbf{6 8 9 0}$ & 8 & 60 & 24 & 21 & 6 & 6890 \\
\hline $\mathbf{5 1 5 1}$ & 26 & 24 & 8 & 34 & 19 & 5151 \\
\hline
\end{tabular}

City 2 Distribution Center

\begin{tabular}{|c|r|r|r|r|r|r|}
\hline Catalog & $\begin{array}{c}\text { Jan } \\
20\end{array}$ & $\begin{array}{c}\text { Feb } \\
20\end{array}$ & $\begin{array}{c}\text { Mar } \\
20\end{array}$ & $\begin{array}{c}\text { Apr } \\
20\end{array}$ & $\begin{array}{c}\text { May } \\
20\end{array}$ & Jun 20 \\
\hline $\mathbf{8 7 5 0}$ & 64 & 35 & 61 & 63 & 67 & 63 \\
\hline $\mathbf{6 8 9 0}$ & 2 & 6 & 6 & 12 & 12 & 12 \\
\hline $\mathbf{5 1 5 1}$ & 16 & 18 & 16 & 25 & 29 & 25 \\
\hline
\end{tabular}

The daily requirement sale is calculated as well the reorder point as the maximum, optimum, and minimum of inventory of finished product Table 8, for each of the distribution centers of the Company, which consider the lead time components. 
Table 8: Supermarket Positioning Distribution Center

DC Central
\begin{tabular}{|c|c|c|c|c|c|}
\hline Catalog & ROP & Inventory & MIN & IDEAL & MAX \\
\hline $\mathbf{8 7 5 0}$ & 171 & 247 & 96 & 139 & 182 \\
\hline $\mathbf{6 8 9 0}$ & 166 & 231 & 93 & 135 & 177 \\
\hline $\mathbf{5 1 5 1}$ & 16 & 49 & 9 & 14 & 19 \\
\hline
\end{tabular}

DC City 1
\begin{tabular}{|c|c|c|c|c|c|}
\hline Catalog & ROP & Inventory & MIN & IDEAL & MAX \\
\hline $\mathbf{8 7 5 0}$ & 17 & 4 & 6 & 13 & 20 \\
\hline $\mathbf{6 8 9 0}$ & 147 & 76 & 52 & 113 & 173 \\
\hline $\mathbf{5 1 5 1}$ & 51 & 35 & 24 & 43 & 63 \\
\hline
\end{tabular}

DC City $\mathbf{2}$
\begin{tabular}{|c|c|c|c|c|c|}
\hline Catalog & ROP & Inventory & MIN & IDEAL & MAX \\
\hline $\mathbf{8 7 5 0}$ & 35 & 18 & 12 & 26 & 41 \\
\hline $\mathbf{6 8 9 0}$ & 17 & 27 & 6 & 13 & 20 \\
\hline $\mathbf{5 1 5 1}$ & 9 & 25 & 5 & 8 & 11 \\
\hline
\end{tabular}

In the manufacturing facility, the production plan Table 9 is analyzed to implement the supermarket and act as a buffer before any variation of supply to ensure the availability of the product. The production plan considers the distribution centers' net requirement, less the positioned inventory on the facility to calculate the requirement to produce.

Table 9: Production Plan - Manufacturing Facility

\begin{tabular}{|l|c|c|c|c|c|c|}
\hline Catalog & $\begin{array}{l}\text { Aug } \\
\mathbf{1 9}\end{array}$ & $\begin{array}{l}\text { Sep } \\
\mathbf{1 9}\end{array}$ & $\begin{array}{l}\text { Oct } \\
\mathbf{1 9}\end{array}$ & $\begin{array}{l}\text { Nov } \\
\mathbf{1 9}\end{array}$ & $\begin{array}{l}\text { Dec } \\
\mathbf{1 9}\end{array}$ & \\
\hline $\mathbf{8 7 5 0}$ & 456 & 332 & 338 & 100 & 325 & \\
\hline $\mathbf{6 8 9 0}$ & 549 & 542 & 467 & 320 & 360 & \\
\hline $\mathbf{5 1 5 1}$ & 38 & 286 & 65 & 241 & 229 & \\
\hline
\end{tabular}

\begin{tabular}{|c|c|c|c|c|c|c|}
\hline Catalog & $\begin{array}{l}\text { Jan } \\
20\end{array}$ & $\begin{array}{l}\text { Feb } \\
20\end{array}$ & $\begin{array}{l}\text { Mar } \\
20\end{array}$ & $\begin{array}{l}\text { Apr } \\
20\end{array}$ & $\begin{array}{l}\text { May } \\
20\end{array}$ & $\begin{array}{l}\text { Jun } \\
20\end{array}$ \\
\hline $\mathbf{8 7 5 0}$ & 430 & 323 & 450 & 449 & 408 & 400 \\
\hline $\mathbf{6 8 9 0}$ & 580 & 493 & 584 & 599 & 469 & 457 \\
\hline $\mathbf{5 1 5 1}$ & 128 & 59 & 191 & 235 & 65 & 65 \\
\hline
\end{tabular}

Determines the supermarket Table 10 for the production area that considers the maximum and minimum inventory policy:

Table 10: Supermarket Manufacturing Facility.

\begin{tabular}{|c|c|c|c|c|c|}
\hline Catalog & ROP & Inventory & MIN & IDEAL & MAX \\
\hline $\mathbf{8 7 5 0}$ & 154 & 130 & 154 & 170 & 185 \\
\hline $\mathbf{6 8 9 0}$ & 212 & 230 & 170 & 212 & 255 \\
\hline $\mathbf{5 1 5 1}$ & 19 & 25 & 10 & 22 & 34 \\
\hline
\end{tabular}

\section{6) Visual Management of the Inventory of Distribution Centers}

The current inventory of finished products is compared against the maximum, optimum, and minimum inventory to maintain visual management. Green indicates that it is within the maximum level and optimum inventory; this is the ideal position. Yellow between the optimum and minimum levels requires planning to place a manufacturing order to replenish the inventory to its position. Red requires expediting the production order, given that the current inventory is below the minimum level with a possible negative impact on the service level. When the current position is www.astesi.com blue, it is above the maximum allowed level, and action is required to balance the inventory levels to those approved. It is essential to run this report daily since it is the tool that manages the release, issuance, and establishment of priorities of the manufacturing orders to production and the valuation of the position of inventory in units. This report is required per the manufacturing facility and distribution center.

\section{7) Planning Horizons}

Once the supermarket was positioned in the Distribution Center and manufacturing facility, the following was agreed with the Commercial area:

The sales estimate horizon is three months (current month plus two months based on the historical demand), delivery takes place between 3 - 4 days business days of the month, and formed on the following and the basis of the planning zones:

- Fixed Zone: Consists of the time required upon releasing the production order and until the product is available for sale. The horizon is of 14 days with zero percentage of variation. This planning zone is conformed of labor, materials, and burden.

- Firm Zone: This zone considers, from the moment the purchase order is placed to the suppliers, considers the longest lead time of the resource, either materials, tools, and/or equipment, as labor in compromising the production requirements. The time horizon is 20 days; the variation percentage of the sale estimated is $+/-20 \%$. In this horizon, planning involves materials and any other resource required to be contracted as labor and/or equipment.

- Planning Zone: Consists of the horizon when no resource for production is committed; therefore, the percentage of variation is open.

\section{8) Delivery Time to Customer Service}

The delivery time to the customer is essential as part of the flexibility offered by the Company, to meet the immediate need for what was agreed with the Commercial area, the following delivery times according to the $\mathrm{ABC}$ classification of the finished product:

- Family Products A: Delivery time is the time upon the receipt of the order, preparation, shipment, and invoicing; this delivery time is of 90 minutes for the external customer; in the case of an internal customer as the Distribution Centers located in other cities, it must be considered two days upon the receipt of the inventory replenishment requirement, preparation of shipment and billing plus the in-transit time. If demand variation consumes the inventory available in the supermarket, the planning area should coordinate the managing of materials and resource capacity with Production and Purchasing; consideration should be given to the delivery to customers and communicate to the commercial area the best delivery commitment to customer's order. In coordination with planning, the Commercial area shall manage the priorities of the inventory allocation until the inventory is regularized in the supermarket according to the maximum and minimum levels of inventories approved. Production should communicate the plan to recover inventory to approved levels. 
- Family Products B: These finished goods products are not supplied within the calculation of the maximum and minimum inventory. It is a product that is managed to make an order basis. Delivery Time is seven days. The way to schedule this finished product to production is FIFO (Customer's First orders entered are the first to be scheduled for production).

- Family Products $C$ : This is a new product with a particular design in which the delivery time is variable according to the project's timeline.

9) Production Balance
Based on the month's production requirement, the production requirement is planned in Table 11,30\% in week 1, 30\% in week $2,20 \%$ in week 3 , and $20 \%$ in Week 4 ; this production balance enables demand confrontation since $60 \%$ of the sale occurs in the last two weeks of the month, which makes the labor requirement planning Table 12 as the materials requirements more predictable, for inventory positioning of raw materials in supermarkets, this enables better visibility of the requirement to the consumption of raw materials to suppliers and increase the flexibility of the productive capacity, especially when they are manufacturing make to order products for special projects for which demand is random.

Table 11: Monthly Balanced Production Plan

\begin{tabular}{|c|c|c|c|c|c|c|c|c|c|c|c|c|c|}
\hline Catalog & $\begin{array}{c}\text { Mont } \\
\text { hly } \\
\text { Prod. } \\
\text { Req" }\end{array}$ & $\begin{array}{c}\text { Pro } \\
\text { d. } \\
\text { Req } \\
\text { Wk } \\
1 \\
\end{array}$ & $\begin{array}{c}\text { Pro } \\
\text { d. } \\
\text { Req } \\
\text { Wk } \\
2 \\
\end{array}$ & $\begin{array}{c}\text { Pro } \\
\text { d. } \\
\text { Req } \\
\text { Wk } \\
3 \\
\end{array}$ & $\begin{array}{c}\text { Pro } \\
\text { d. } \\
\text { Req } \\
\text { Wk } \\
4 \\
\end{array}$ & $\begin{array}{c}\text { Hr. } \\
\text { Req } \\
\text { Proce } \\
\text { ss 1 } \\
\text { Wk1 } \\
\end{array}$ & $\begin{array}{c}\text { Hr. } \\
\text { Req } \\
\text { Proce } \\
\text { ss } 2 \\
\text { Wk1 } \\
\end{array}$ & $\begin{array}{c}\text { Hr. } \\
\text { Req } \\
\text { Proce } \\
\text { ss 1 } \\
\text { Wk2 } \\
\end{array}$ & $\begin{array}{c}\text { Hr. } \\
\text { Req } \\
\text { Proce } \\
\text { ss } 2 \\
\text { Wk2 } \\
\end{array}$ & $\begin{array}{c}\text { Hr. } \\
\text { Req } \\
\text { Proce } \\
\text { ss 1 } \\
\text { Wk3 } \\
\end{array}$ & $\begin{array}{c}\text { Hr. } \\
\text { Req } \\
\text { Proce } \\
\text { ss } 2 \\
\text { Wk3 } \\
\end{array}$ & $\begin{array}{c}\text { Hr. } \\
\text { Req } \\
\text { Proce } \\
\text { ss 1 } \\
\text { Wk4 } \\
\end{array}$ & $\begin{array}{c}\text { Hr. } \\
\text { Req } \\
\text { Proce } \\
\text { ss } 2 \\
\text { Wk4 } \\
\end{array}$ \\
\hline Product 1 & 493 & 148 & 148 & 99 & 99 & 166 & 243 & 166 & 243 & 111 & 162 & 111 & 162 \\
\hline Product 2 & 323 & 97 & 97 & 65 & 65 & 109 & 159 & 109 & 159 & 73 & 106 & 73 & 106 \\
\hline Product 3 & 59 & 18 & 18 & 12 & 12 & 8 & 16 & 8 & 16 & 5 & 11 & 5 & 11 \\
\hline Product 4 & 0 & 0 & 0 & 0 & 0 & 0 & 0 & 0 & 0 & 0 & 0 & 0 & 0 \\
\hline Product 5 & 232 & 70 & 70 & 46 & 46 & 63 & 63 & 63 & 63 & 42 & 42 & 42 & 42 \\
\hline Product 6 & 0 & 0 & 0 & 0 & 0 & 0 & 0 & 0 & 0 & 0 & 0 & 0 & 0 \\
\hline Product 7 & 145 & 44 & 44 & 29 & 29 & 49 & 71 & 49 & 71 & 33 & 48 & 33 & 48 \\
\hline Product 8 & 430 & 129 & 129 & 86 & 86 & 145 & 212 & 145 & 212 & 97 & 141 & 97 & 141 \\
\hline Product 9 & 1 & 0 & 0 & 0 & 0 & 1 & 3 & 1 & 3 & 1 & 2 & 1 & 2 \\
\hline Product 10 & 57 & 17 & 17 & 11 & 11 & 19 & 51 & 19 & 51 & 13 & 34 & 13 & 34 \\
\hline Product 11 & 40 & 12 & 12 & 8 & 8 & 14 & 36 & 14 & 36 & 9 & 24 & 9 & 24 \\
\hline Product 12 & 151 & 45 & 45 & 30 & 30 & 27 & 20 & 27 & 20 & 18 & 14 & 18 & 14 \\
\hline Product 13 & 241 & 72 & 72 & 48 & 48 & 43 & 33 & 43 & 33 & 29 & 22 & 29 & 22 \\
\hline Product 14 & 78 & 23 & 23 & 16 & 16 & 14 & 11 & 14 & 11 & 9 & 7 & 9 & 7 \\
\hline Product 15 & 372 & 112 & 112 & 74 & 74 & 67 & 50 & 67 & 50 & 45 & 33 & 45 & 33 \\
\hline Product 16 & 300 & 90 & 90 & 60 & 60 & 54 & 41 & 54 & 41 & 36 & 27 & 36 & 27 \\
\hline Product 17 & 109 & 33 & 33 & 22 & 22 & 20 & 15 & 20 & 15 & 13 & 10 & 13 & 10 \\
\hline Product 18 & 92 & 28 & 28 & 18 & 18 & 25 & 83 & 25 & 83 & 17 & 55 & 17 & 55 \\
\hline Product 19 & 165 & 50 & 50 & 33 & 33 & 22 & 22 & 22 & 22 & 15 & 15 & 15 & 15 \\
\hline Product 20 & 218 & 65 & 65 & 44 & 44 & 0 & 75 & 0 & 75 & 0 & 50 & 0 & 50 \\
\hline Product 21 & 1089 & 327 & 327 & 218 & 218 & 0 & 399 & 0 & 399 & 0 & 266 & 0 & 266 \\
\hline \multicolumn{6}{|c|}{ Wk Req. hrs. } & 540.1 & 762.9 & 540.1 & 762.9 & 360.0 & 508.6 & 360.0 & 508.6 \\
\hline \multicolumn{6}{|c|}{ Daily Req. hrs. } & 90.0 & 127.2 & 90.0 & 127.2 & 60.0 & 84.8 & 60.0 & 84.8 \\
\hline
\end{tabular}

Table 12: Labor Weekly Requirement

\begin{tabular}{|l|c|c|c|c|c|c|c|c|}
\hline & \multicolumn{9}{|c|}{ Wabor Weekly Requirement } \\
\cline { 2 - 10 } & $\begin{array}{c}\text { Process } \\
1\end{array}$ & $\begin{array}{c}\text { Process } \\
2\end{array}$ & $\begin{array}{c}\text { Process } \\
1\end{array}$ & $\begin{array}{c}\text { Process } \\
2\end{array}$ & $\begin{array}{c}\text { Process } \\
1\end{array}$ & $\begin{array}{c}\text { Process } \\
2\end{array}$ & $\begin{array}{c}\text { Process } \\
1\end{array}$ & $\begin{array}{c}\text { Process } \\
2\end{array}$ \\
\hline $\begin{array}{l}\text { Product } \\
\text { Family 1 }\end{array}$ & 9.7 & 14.1 & 9.7 & 14.1 & 6.5 & 9.4 & 6.5 & 9.4 \\
\hline $\begin{array}{l}\text { Product } \\
\text { Family 2 }\end{array}$ & 7.8 & 11.2 & 7.8 & 11.2 & 5.2 & 7.4 & 5.2 & 7.4 \\
\hline $\begin{array}{l}\text { Product } \\
\text { Family 3 }\end{array}$ & 1.7 & 1.8 & 1.7 & 1.8 & 1.1 & 1.2 & 1.1 & 1.2 \\
\hline $\begin{array}{l}\text { Product } \\
\text { Family 4 }\end{array}$ & 0.9 & 1.8 & 0.9 & 1.8 & 0.6 & 1.2 & 0.6 & 1.2 \\
\hline
\end{tabular}


TIME PER EVENT

$03: 21$

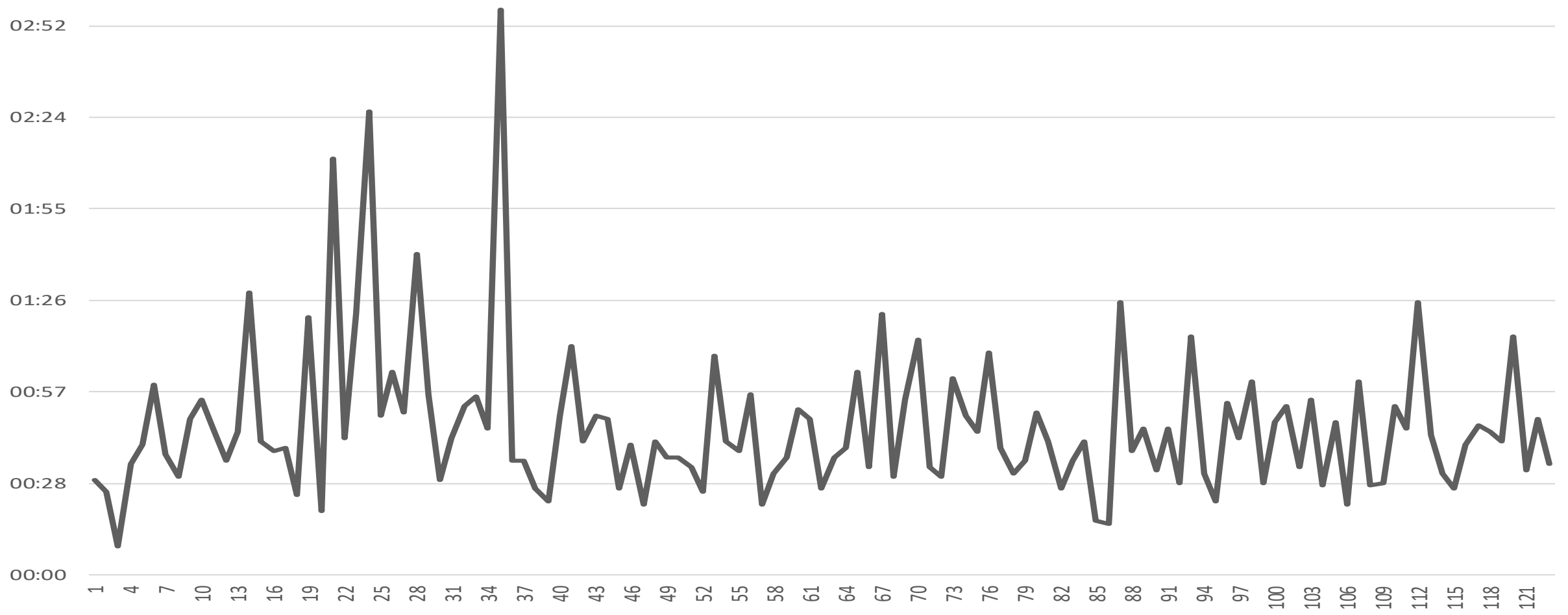

Figure 6: Customer delivery Time per event. 


\section{0) Customer delivery Time}

The customer delivery time Figure 6 is measured from the moment the customer order is created, the administration area authorizes the order, the ordered product inventory is booked, delivery of documents to logistics, processing the loading order, delivery of documents to the loading area, loading of order and delivery of documents to the customer.

Registers an average customer delivery time of 46 minutes below the goal of 90 minutes, which encourages the customer to be recurrent customers considering the availability of inventory to cover their requirements with a short delivery time.

\section{1) Process Capability and Six Sigma}

Through the implementation of the proposed improvements, the process is in statistical control, as well as in the assessment of capability indexes, the level of cpk increased from 0.37 to 0.86 , the associated $\mathrm{z}$ level moved from 1.11 to 2.59 , and the sigma level moved from 2.61 to 4.09 with a decrease of defects per million of 133,519 to $4,798.83$. It should be noted that an optimum level is not yet achieved. However, this represents a strategic impact and the opportunity to deploy additional improvements to arrive at an ideal level of six sigma, that is to say, with only 3.4 ppm of failure. It can be observed in Figure 7 that the associated data with the subsequent measurements to improvements come from a normal distribution with a $\mathrm{p}$ value $=0.407$, which is higher than the value $\alpha=0.05$ [23].

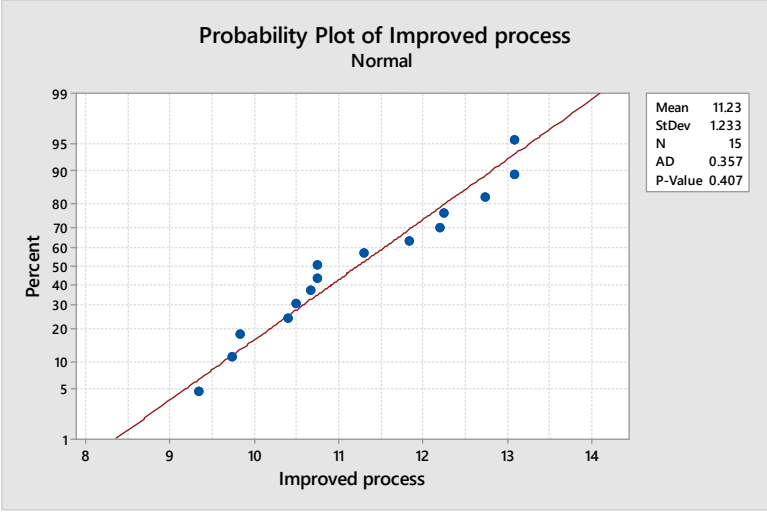

Figure 7: Probability Plot of Improved Process

Figure 8 shows the process under statistical control without points outside the control limits without any anomaly trends.

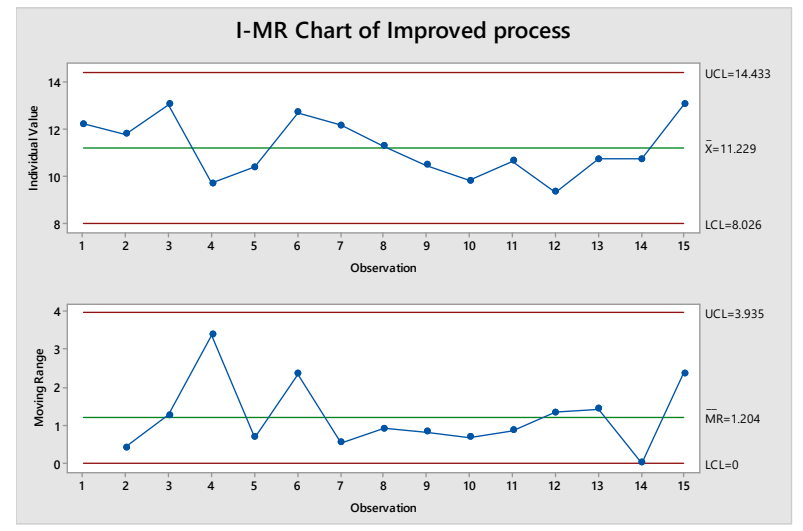

Figure 8: Graph of Individual Values and Mobile Range for the Improved Process
Figure 9 shows the process capability analysis report in which it is possible can see the improvements obtained with a Cpk index of 0.86; although it is not the optimal state of the process represents a significant improvement.

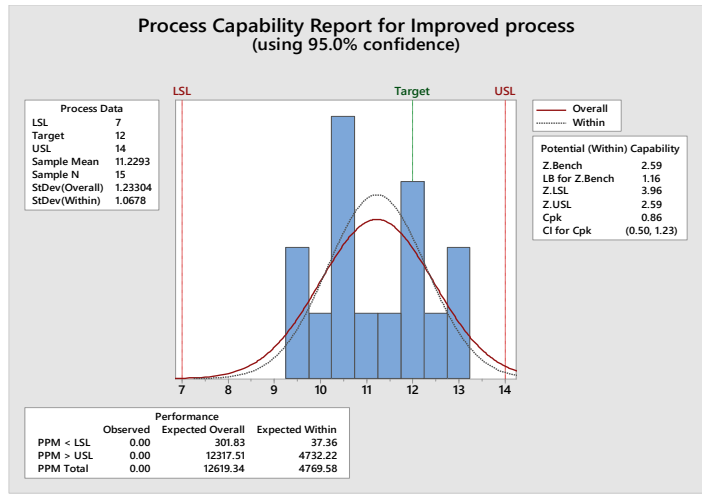

Figure 9: Process Capability Report for Improved process

Figure 10 shows the improvement in performance in which there is a significant reduction in the fraction of the probability distribution outside the upper limit of the specification.

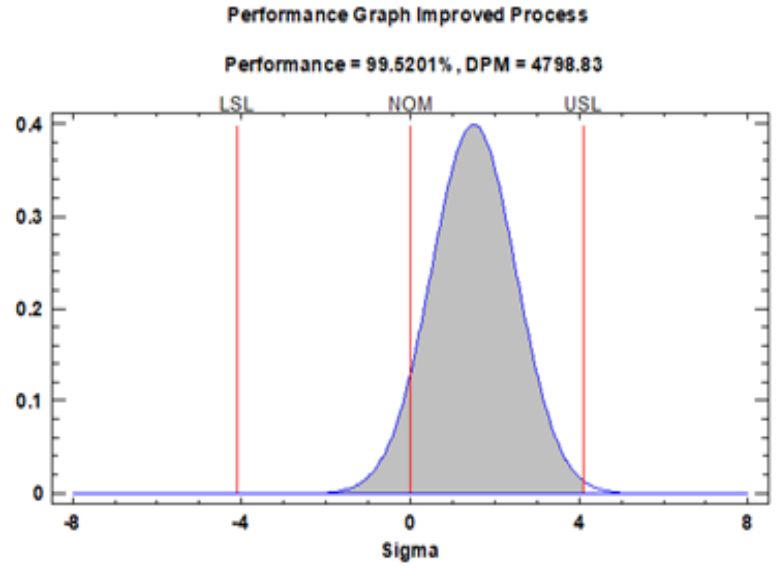

Figure 10: Performance Graph Improved Process

Table 13 shows the values obtained in the six-sigma calculator associated with the improved process the $\mathrm{Z}$ value of 2.59 , Defects Per Million (DPM) of 4,798.33, Percentage of Defects 0.47 , Yield of $99.52 \%$ with a process capability $(\mathrm{Cpk})$ of 0.86 , and a sigma quality level of (SQL) 4.09 .

Table 13: Six Sigma Calculator Entry: Value-Z $=2.59$, Change in sigma $=1.5$ Equivalent values

\begin{tabular}{|l|r|}
\hline Table of Contents & \multicolumn{1}{|c|}{ Value } \\
\hline Value-Z & 2.59 \\
\hline DPM & 4798.83 \\
\hline Defects & 0.479883 \\
\hline Performance & 99.5201 \\
\hline Cpk & 0.863333 \\
\hline SQL & 4.09 \\
\hline
\end{tabular}

\section{2) Pull System}

The Commercial area estimates the monthly sales to determine the maximum and minimum level of finished product inventory. A pull system is implemented, the customer's orders are supplied directly from the CD's finished good product supermarket. The 


\section{DAYS OF SUPPLY CHART TREND 2019 - 2020}

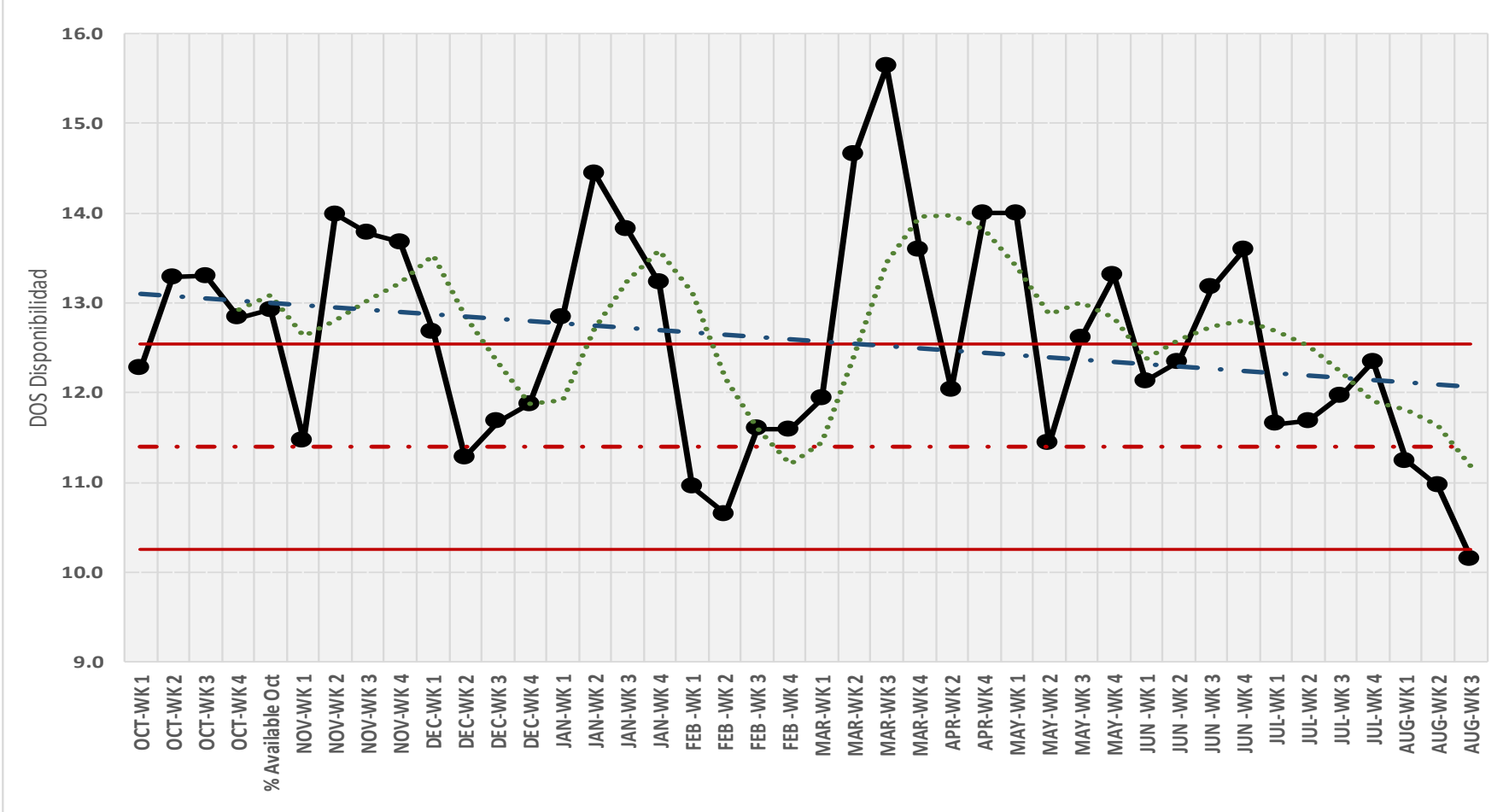

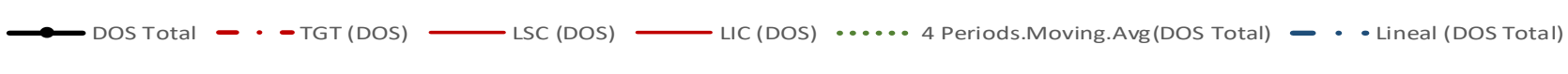

Figure 11: Days of Supply Finished Goods Inventory

consumption of the supermarket inventory generates a manufacturing order for production to replenish the finished product supermarket. As the supermarket's raw materials are consumed when producing the manufacturing orders, the purchasing requisitions of raw material are released to the purchasing department to generate the purchase orders for the suppliers and thus guarantee the replenishment in the raw's materials supermarket.

\section{3) Days of Supply Finished Goods Inventory}

The trend chart of days of supply Figure 11 shows a favorable trend in days of coverage, having a supply of twelve days of inventory against a goal of 14 days.

\section{Results and Conclusions}

During the COVID 19 pandemic, the Company has been operated with a Pull system, in which supermarkets were positioned in Central, City 1, and City 2 distribution centers for finished products classified A; The inventory is managed with a maximum, and minimum policy, based on customer consumption, the supply signal to the manufacturing plant is triggered to replenish and position the inventory in the distribution centers.
Based on the inventory consumption for the supermarket of the manufacturing plant, the manufacturing orders are released to replenish the inventory in the supermarket of the plant, which has generated a reduction of the inventory to a coverage of 12 days before starting the improvement in the process, the catalogs classified type A had a 27-day average coverage, against the Company's goal of 14 days of inventory. The service level, the baseline of performance $89 \%$ guaranteeing inventory availability, exceeds expectations with a 98\% service level. An average customer delivery time of 46 minutes is recorded below the 90minute goal, which encourages the customer to be a recurring customer considering inventory availability to meet their requirements with lead time delivery. The savings in inventory optimization on an annual basis represented USD 530,785. (Five hundred thirty thousand seven hundred eighty-five dollars) helping the Company to gain liquidity and to create the conditions for the recovery of economic growth, and helping to preserve employment as much as possible in a constrained market. Through the implementation of the proposed improvements, the process is under statistical control, the process capability (Cpk) is increased from 0.37 to 0.86 , and the level six sigma (SQL) is increased from 2.61 to 4.09 , reducing the percentage of defects to 
13.3 to 0.47 . An additional benefit is that the Company implemented the methodology nationwide in its other Manufacturing Plants and Distribution Centers. This methodology supports the acceptable practices that the Company is implementing in search of continuous improvement as part of the strategic framework to fulfill the strategic objectives based on the business vision.

\section{Conflict of Interest}

The authors declare no conflict of interest.

\section{Acknowledgment}

The corresponding author wants to acknowledge the Popular Autonomous University of the State of Puebla (UPAEP University).

\section{References}

[1] B. Keyte, D.A. Locher, The Complete Lean Enterprise: Value Stream Mapping for Administrative and Office Processes, CRC Press, 2004.

[2] R. Martichenko, K. Von Grabe, Building a Lean Fulfillment Stream, Lean Enterprise Institute, 2010.

[3] M. Imai, Kaizen: La clave de la ventaja competitiva japonesa, Compañía Editorial Continental, 2000.

[4] J.P. Womack, D.T. Jones, Lean Thinking: Banish Waste and Create Wealth in Your Corporation, Simon \& Schuster, 1996.

[5] J.K. Liker, The Toyota Way: 14 Management Principles from the World's Greatest Manufacturer, McGraw-Hill, 2004.

[6] S. Emmett, Excellence in warehouse management, Wiley, 2005.

[7] M. Malindzakova, D. Zimon, "Design Supply Cycle for Inventory Management," TEM Journal, 8(3), 894-899, 2019, doi: 10.18421/TEM8329.

[8] S. Kumar, D. Choe, S. Venkataramani, "Achieving customer service excellence using Lean Pull Replenishment," International Journal of Productivity and Performance Management, 62(1), 85-109, 2012, doi: $10.1108 / 17410401311285318$

[9] L. Cuatrecasas-Arbós, J. Fortuny-Santos, P. Ruiz-de-Arbulo-López, C. Vintró-Sanchez, "Monitoring processes through inventory and manufacturing lead time," Industrial Management \& Data Systems, 115(5), 951-970, 2015, doi: 10.1108/IMDS-12-2014-0375.

[10] R. Rodríguez-Méndez, D. Sánchez-Partida, J.L. Martínez-Flores, E. ArvizuBarrón, "A case study: SMED \& JIT methodologies to develop continuous flow of stamped parts into AC disconnect assembly line in Schneider Electric Tlaxcala Plant," IFAC-Papersonline, 48(3), 1399-1404, 2015, doi: https://doi.org/10.1016/j.ifacol.2015.06.282.

[11] D. Sánchez-Partida, R. Rodríguez-Méndez, J.L. Martínez-Flores, S.O. Caballero-Morales, "Implementation of Continuous Flow in the Cabinet Process at the Schneider Electric Plant in Tlaxcala, Mexico," Interfaces, 48(6), 566-577, 2018, doi: 10.1287/inte.2018.0966.

[12] Y. Ge, Y. Ye, "A bibliometric analysis of inventory management research based on knowledge mapping," The Electronic Libray, 37(1), 127-154, 2018, doi: 10.1108/EL-11-2017-0241.

[13] Y. Lin, B. Liang, X. Zhu, "The effect of inventory performance on product quality: The mediating effect of financial performance," International Journal of Quality and Reliability Management, 35(10), 2227-2247, 2018, doi: 10.1108/IJQRM-08-2017-0162.

[14] N.A. Karim, A. Nawawi, A.S. Salin, "Inventory control weaknesses - a case study of lubricant manufacturing Company," Journal of Financial Crime, 25(2), 436-449, 2018, doi: 10.1108/JFC-11-2016-0077.

[15] R.H. Teunter, M.Z. Babai, A.A. Syntetos, "ABC Classification: Service Levels and Inventory Costs," Production and Operations Management, 19(3), 343-352, 2009, doi: 10.1111/j.1937-5956.2009.01098.x.

[16] J. Shook, T. Narusawa, Kaizen express: Fundamentals for your Lean Journey, The Lean Enterprise Institute, 2009.

[17] D. Kumar, D. Kumar, "Managing the essential medicines stock at rural healthcare systems in India," International Journal of Health Care Quality Assurance, 31(8), 950-965, 2018, doi: 10.1108/IJHCQA-12-2016-0186.

[18] E.M. Goldratt, J. Cox, The Goal: A Process of Ongoing Improvement, North River Press, 1986.

[19] E.M. Goldratt, J. Cox, The Race, North River Press, 1986.
[20] G. Richards, S. Grinsted, The logistics and supply chain toolkit, Kogan Page Limited, 2016.

[21] K.B. Ackerman, Auditing Warehouse Performance, Ackerman Publications, 2003.

[22] H. Singh, A. Singh, "Application of lean manufacturing using value stream mapping in an auto-parts manufacturing unit," Journal of Advances in Management Research, 10(1), 72-84, 2018, doi: $10.1108 / 09727981311327776$

[23] T.M. Kubiak, D.W. Benbow, The certified Six Sigma Black Belt Handbook, American Society for Quality, 2009. 